\title{
Towards a Successful Integration of Project-based Learning in Higher Education: Challenges, Technologies and Methods of Implementation
}

\author{
Raz Shpeizer \\ Department of Post-Graduate Teacher Education, Kaye Academic College of Education, Israel
}

Copyright $\mathrm{C} 2019$ by authors, all rights reserved. Authors agree that this article remains permanently open access under the terms of the Creative Commons Attribution License 4.0 International License

\begin{abstract}
Project-based learning (PBL) is a learner-centered teaching method that seeks to enable students to develop themselves and their knowledge through means relevant to their lives. The structural principles of the method reflect contemporary knowledge regarding the importance of autonomy, activity, and collaboration in learning, and harmonize well with the information age and its technologies. Despite these, however, project-based learning implementation in higher education has been slow and accompanied by difficulties. In this paper, I review the main features of project-based learning, the advantages it offers to higher education, and the main challenges that its successful implementation faces. On the basis of a synthesis between theoretical and practical knowledge, I present and demonstrate ways for integrating the project-based learning principles with available information and communications technologies, and offer implementation guidelines for lecturers and institutions of higher education.
\end{abstract}

Keywords Project-based Learning (PBL), Higher Education, Information and Communications Technologies (ICT), Implementation

Education is a process of living and not a preparation for future living (John Dewey, 1897, p. 88)

\section{Introduction}

The last few decades have seen a dramatic change in the world of education that could be described theoretically if not always practically - as a paradigm change. This paradigm shift may be defined as the transition from a traditional teacher-centered and subject-centered teaching to a student-centered approach, in which the student's needs, interests and learning processes constitutes the main focal point (Lathika, 2016;
Nanney, 2004). At the root of this change stand two main sources: research, which discovered or sometimes re-discovered the importance for learning of inner motivation and autonomy, social and constructivist processes, and active real-life experience; and the technological changes that brought about the communication and information revolution, which vastly broadened the realm of human communication and interaction, and to a large extent made the old way of teaching which focused on redundant knowledge transmission.

The realm of K-12 have absorbed at least some of these changes by adopting new ways of teaching and learning and integrating them - in varied degrees and forms - into the existing system. The vast majority of academic institutions, however, have adhered to the traditional approach (e.g. Saulnier, Landry, Longenecker, and Wagner, 2008), thus creating an ever-growing gap between the academic world, and, especially the needs of higher education students, and the real, fast-changing world. New teaching methods are thus needed in higher education in order to keep it relevant to students' lives both inside and outside the classrooms. One of the methods most suited for this task is project-based learning (PBL), ${ }^{1}$ which both utilizes the theoretical development in the educational field and fits in with the new technological and social order. Indeed, as will be demonstrated, the modern ICT (information and communications technologies) integrate well with PBL both as a learning tool and as a means to promote PBL's underlying pedagogical agenda. However, the integration of the two - like the overall integration of PBL in the higher education system - also pose some challenges, especially regarding lecturers' understanding of the method and technological skills, as well as the danger of turning technology as an end in itself.

Therefore, in this paper I explore the main features of project-based learning, the advantages it offers to higher education, and the main challenges its successful 
integration faces within it. I then present and demonstrate ways for integrating information and communications technologies in the teaching of PBL, in order to advance its integration in higher education and promote its pedagogical agenda, and offer some implementation guidelines for lecturers and institutions of higher education.

\section{Project-based Learning}

According to one of the most popular definitions, project-based learning is a teaching method that:

engages students in learning knowledge and skills through an extended inquiry process structured around complex, authentic questions and carefully designed products and tasks (Markham, Larmer and Ravitz, 2003, p. 4).

The goal of this method is to promote the learning of knowledge, skills, and dispositions by enhancing students' engagement in the learning processes and by emphasizing the practical dimension of learning and its relevance to students' lives and to the society in which they live. PBL has similar characteristics to other learning methods, such as problem-based learning and inquiry-based learning. ${ }^{2}$ Like these methods, it centers on independent inquiry learning of students and transfers to the students much of the responsibility for the learning processes and their outcomes. PBL has several basic characteristics that combine to form its unique character. These include:

In-depth inquiry. The demand to apply a strict academic approach to research and to engage in a full inquiry process, including phrasing questions, finding sources, collecting information, analyzing and synthesizing the findings, and applying the information.

Authenticity. The project should include realistic components that go beyond simulation or a hypothetical exercise and connect the project to the real world (Thomas, 2000). These components include, for example, the final product, the quality criteria of the project, tools used throughout the project, or the audience to which the project is presented.

Active learning. The students are creative partners in the processes of constructing and applying the knowledge (Biggs, 1999; De Los Ríos et al., 2010).

Freedom and autonomy. Some of the decisions concerning the content and means of learning and the implementation of the project are taken independently by the students.

Challenging questions or problems. The learning is based on questions or problems, and the search for the answers motivates the learning processes and the project. In order to meet the requirements of in-depth inquiry and authenticity, the questions and problems should be structured in a manner that provides an opportunity for thorough learning, be interesting to the students, and be relevant to their world. For these reasons, it is desirable that the students participate in formulating the questions or problems.

Collaborative learning. Although theoretically PBL work can take place individually, the strong preference is for collaborative learning in small groups (e.g., Yiping and MacGregor, 2004). This preference is connected to the view that learning is a social process (Vygotsky, 1978), and it further supposes that collaborative work encourages the students to be more involved and responsible (Donnelly, 2005), and also helps them to improve their social skills.

Product and product presentation. Every project should yield a final product (see, e.g., Altay, 2013), and the final product should be presented and explained to an audience, preferably one that has an interest in the project and that goes beyond the confines of the classroom. The possible range of products is large and includes, for example, presentations, short films, exhibitions, programs for enhanced efficiency, games, and instruments. Even though the learning produced throughout the entire process is the main goal of the project rather than the final product, the latter is certainly an essential component of the method, giving it its unique task-oriented and practical quality and helping to distinguish it from its pedagogic relatives (Donnelly, 2005).

\section{PBL in Higher Education}

As aforementioned, PBL is not integrated in higher education in a systematic manner. Its integration can mainly be found in the various fields of engineering with which PBL has traditionally been identified (De Graaff and Kolmos, 2007) and in institutions that have an interest in pedagogic innovation, such as teacher training colleges. A number of academic institutions (such as Twente University in The Netherlands and Aalborg University in Denmark) have adopted PBL as a central teaching method, but it is completely absent from many institutions, while in others it is used on a limited and irregular scale (Harmer, 2014). The limited implementation of PBL in academia goes against the expectations of advocates of the method, particularly in light of the advantages it offers (Lee et al., 2014). The following are some of the most prominent advantages mentioned by researchers:

Enhanced student motivation, due to the possibility students have to choose topics and working methods they prefer. The authenticity of the work, that is, its connection to the real world also contributes to motivation (Saukkonen, 2014).

Learning of various skills, thanks to the emphasis on in-depth inquiry, independent work (individual and group), and a tangible outcome. All these require the students to integrate and develop their studying, collaboration and execution abilities 
Good preparation for a professional career, thanks to the experience of authentic situations and the opportunities to establish contacts with community and professional partners who constitute the students' future work and career environment (De Los Ríos et al., 2010; VasilienèVasiliauskienè, Butviliene and Butvilas, 2016).

Suitability for a wide range of students and learning styles, thanks to the relative autonomy in selecting learning methods and the possibility of dividing the work between group members (Kahn and O'Rourke, 2004).

Suitability for the information age. PBL encourages students to use the full range of modern communications and information technologies. These technologies offer access to information and data, provide a foundation for a range of possible products, and expand the possibilities of communication between the groups, between group members, and between the students and lecturers (Donnelly, 2005; Thomas, 2000; Yiping and MacGregor, 2004). This means that the place and function of ICT in the scheme of PBL are different from its place and function in general standard teaching, because ICT is not being used in PBL only as a learning tool for acquiring different kinds of (usually disciplinary) content, but also as means to promote PBL's student-centered goals of independent, active, social-oriented learning. What is more, ICT serves PBL's core goal of real-life experience by offering the students a meeting point with the real world, both by being a real modern working and living tool, and by connecting the students to the ongoing stream of contemporary life well beyond the classroom.

Alongside the advantages, challenges are also encountered in the successful implementation of PBL in higher education. The three main challenges indicated in studies are:

Changes in the roles of lecturers and students. The PBL method imposes greater responsibility for learning on the students than regular learning, while the lecturers become guides and facilitators. The change in roles and responsibilities - both for students and for lecturers - may lead to uncertainty regarding methods of implementation (Bradley-Levine et al., 2010).

Collaborative work. Group work can have disadvantages, such as conflicts between students, "hitchhikers" who contribute little, and coordination difficulties. According to the studies, most of the disadvantages are due to the lack of experience in joint learning and a lack of skills required for this type of learning (Pawson et al., 2006).

Evaluation. Lecturers must evaluate not only the product but also the process, the skills acquired, and individual and group work. Moreover, evaluation also plays a significant role in improving the students' learning (formative evaluation). Evaluation of this type requires the lecturers to be familiar with diverse evaluation methods, and in some cases to deviate from the usual evaluation procedures used in the academic system.

\section{Technologies and Methods for Implementing PBL in Higher Education}

The implementation of PBL in higher education has been accompanied, almost from the outset, by the integration of technology (i.e., mainly ICT). This integration is only natural given the reasons outlined above. The extent of integration of technology in PBL varies; in some courses it is only integrated in part of the learning, while in others the learning and project are completely based on technology. While the successful integration of technology in PBL teaching can enhance the effectiveness of the method, advance its goals, and facilitate its implementation, it should be remembered that the use of technology does not guarantee the success of learning; technology should be used in an informed manner and adapted to the pedagogical goals (Frank and Barzilai, 2004), and lecturers should resist the road which leads to technology becoming the main issue and target of learning.

The integration of technology in PBL teaching is sometimes carried out through the development of special and dedicated tools for teaching, such as software programs intended to increase the efficiency of the division of students into groups (e.g., Henri, 2015), or special websites intended to facilitate the processes of collaboration and evaluation. However, most of the integration of technology in PBL teaching takes place through the use of existing technological tools. In what follows I explore the most prominent of these tools and the ways they can facilitate the implementation of PBL and the pedagogical principles at its core in higher education.

\subsection{Learning Management System (LMS)}

Almost all institutions of higher education around the world now use learning management systems intended to help in the teaching-learning processes by creating a computerized environment that could be organized according to the pedagogical goals and needs. A wide range of LMS are in use in higher education, such as Moodle, Blackboard, and Canvas; however, most of these systems offer similar characteristics and the differences between them revolve around how different LMS use these characteristics and the support system for each product (Logan and Neumann, 2010).

LMS provide an answer for the basic needs of a computerized work environment in PBL. They provide virtual space for the management of discussions between students, for coordinating the work, and for organizing sources (Tolsby, Nyvang and Dirckinck-Holmfeld, 2002), thereby encouraging collaboration between the students and contributing to the group work. Two of the LMS tools that enable the maximization of the characteristics of PBL 
and offer a response to the challenges involved in its implementation are the peer evaluation application and the blog, both of which support the formative evaluation system required in PBL. For example, the lecturer can track the blogs (individual or group, private or public), offer feedback to the writers during the process, and monitor their activities and progress in the project. Another important tool is the wiki, which permits joint creation of information and content pages. The wiki is particularly suited to $\mathrm{PBL}$, since it encourages the independent structuring of knowledge while developing such skills as critical thinking, collaboration, and communication. Wikis can be used in diverse ways and different degrees to promote the learning and the projects. For example, in the English language school at the University of Birmingham in England the wiki was used to summarize the group discussions and create an archive of group activities (Page, 2008). In an information and technology systems course at Victoria University in New Zealand, the wiki was used to create a knowledge base, and formed a part of the final product, which consists of a literature review and class presentation (Elgort, Smith and Toland, 2008).

\subsection{Google Tools}

Google offers a diverse range of tools permitting, for example, the storage of materials (Google Drive); independent research (Google Books, Google Scholar); collaborative work (Google Groups, Google +, Google Docs); and the creation of virtual products (Google Docs, Google Slides, Google Sites). Two important advantages of the Google tools are their accessibility - to any user from any device with internet capability - and the fact that they form part of the real world in which the students act and will act in their non-academic lives.

As in the case of LMS, Google tools can be used to varying degrees and in different combinations depending on the learning goals. Some lecturers simply use Google Drive to upload materials, providing students with some preliminary orientation to the course, while others use Google Docs to monitor the students' learning processes and to provide feedback (the ability to view the personal contribution of each participant even in group documents allows for a combination of individual and group evaluation). In one of my courses, Introduction to the Philosophy of Education, the students used Google Docs to create a lexicon of the philosophy of education. During their work on the lexicon entries, each group received online feedback from the instructors on the drafts uploaded, in addition to peer feedback provided in person. The final product was stored on Google Drive and exposed to the public by means of hyperlinks sent to academic websites. Thus, the elements of group and independent work, formative evaluation, and an authentic product were brought into practice.

\subsection{Mobile Technology}

The term mobile technology is a catchall name for technological means, such as tablet computers, portable drives, and smartphones, that can be easily carried from one place to another and allow immediate access to information (Dearnley et al., 2009). Despite the enormous progress that has been made in the capabilities and accessibility of mobile technology, little use is made of these tools in academic teaching, including teaching using the PBL method. However, some studies (e.g., Utulu and Alonge, 2012) have shown that students who learn in PBL courses use mobile technology - and particularly smartphones - even though they have not been instructed to do so. For this reason, mobile technology expands and empowers the technological elements that integrate so successfully with PBL, it is recommended that this technology be used in a structured manner in order to advance and implement the method.

Mobile devices can be used to document the learning processes. Such documentation can also be useful in managing and evaluating the project. Applications such as Evernote and Voice Thread facilitate the documentation, saving, and sharing of different types of media, as well as the planning of learning processes and the management of project execution. ${ }^{3}$ The lecturer can ask the students to collate evidence in a portfolio forming part of the evaluation process, or can provide feedback for the students at various milestones during the process in order to guide and improve their work. Applications such as WhatsApp and Google Diary, which are convenient for students to use and popular with them (Srba, 2010), allow the rapid exchange of messages and coordination between the members of groups. The mobility of the devices involved promotes the authenticity of learning, that is, its integration in the real world. Students can use the applications during their meetings with community partners, while investigating places and while collecting data from the field. In the Environmental Biology course at McGill University in Canada, for example, the students go out into the field equipped with tablet computers. ${ }^{3}$ This enables them to collect information about the flora and fauna they encounter, to share their findings with each other, and to document the findings as a foundation for ongoing research (Buddle, 2013).

The range of applications for mobile devices is vast. However, uncontrolled use of them, for example, a demand to simultaneously use several applications or to learn a number of new applications at once, may cause flooding and confusion. Therefore, the course lecturer should ensure that all the students know how to work with the applications used in the course, and should suggest specific applications. Nevertheless, in keeping with the spirit and goals of PBL, the students should be allowed to choose some of the applications they wish to use. 


\section{Additional Methods and Means}

Technology alone cannot guarantee the implementation of PBL in higher education. As a method that deviates from the common pattern of teaching-learning, PBL raises quite a few inherent challenges for its realization. In order to meet these challenges, there is a need for the institution to mobilize in order to provide an infrastructure for the implementation of the method and solutions to its challenges. This mobilization needs to take place on several levels:

The ideological level. The institution must recognize the importance of PBL and the principles it represents. Without such recognition it will be impossible to carry out the additional levels detailed below (Lee et al., 2014).

The remuneration level. The institution must recognize the additional time and effort that are required by both lecturers and students in PBL courses (Donnelly and Fitzmaurice, 2005).

The support and training level. As noted, most of the difficulties faced by students and lecturers in implementing PBL are due to the changes the method requires in their roles and functions. Studies (e.g., Lee et al., 2014; Mills and Treagust, 2003) have repeatedly demonstrated the need to provide preparatory training in PBL for the lecturers, particularly in facilitation and evaluation skills. At Twente University, for example, all new lecturers are required to participate in a program devoted in part to PBL (Weenk, Govers and Vlas, 2004), while the University of Indianapolis in the US holds professional development programs in PBL that combine study and the planning of courses (Lee et al., 2014). Regarding students, most of the learning of skills should take place during the project implementation processes. However, preliminary preparation and attentive guidance may reduce anxiety and frustration and help students cope with problems. At Alborg University where PBL serves as a basic pedagogic strategy, first-year students attend a course on collaborative learning and project management (Lehmann et al., 2008). If such courses are not provided, it is important that lecturers present students with the foundations of the method and guidelines for its implementation. In any case, the lecturers must provide close yet flexible supervision, enabling and encouraging the students to learn independently and responsibly while responding attentively to difficulties and showing a willingness to help when necessary.

Clearly, technology can also be used to enhance the efficiency of these methods. Today, institutions of higher education interested in promoting PBL devotes a website to the method, which includes materials and links intended for use by both lecturers and students. Similarly, lecturers can take advantage of the websites available to them on the learning management systems in their institutions in order to introduce the method to students, courses and goals, and provide support on demand.
Lastly, another important method for advancing and maximizing the advantages of PBL is the creation of connections with other bodies in the community. These may be commercial, voluntary, private, or state bodies. The integration of students and of the project in such bodies outside the academic world will immerse students in real-life situations and can be expected to increase their interest and motivation. Moreover, such cooperation can advance students' careers and, at the same time, contribute to the community and to society (De Los Ríos et al., 2010). Thus, the two most important elements of PBL are manifested: The integration of the personal and the social, and the combination of the theoretical and the practical.

\section{Notes}

1. The acronym "PBL" is used in the literature to denote both problem-based learning and project-based learning. Here I will use it only for the latter.

2. Researchers disagree regarding the precise distinction between these methods, and particularly regarding the distinction between project-based learning and problem-based learning. A detailed discussion of this problem is not desirable in this article, since it would distract from its central theme, but in what follows I shed some light on the unique character of PBL. For further discussion on the subject see: Harmer (2014).

3. For references to the homepages of these and other applications, together with explanations, see: Educational Technology and Mobile Learning (2014). Although the course mentioned is conducted in the format of inquiry-based learning, its execution method is relevant also for PBL.

\section{REFERENCES}

[1] Altay, B. (2013). User-Centered Design through Learner-Centered Instruction. Teaching in Higher Education, 19(2), pp. 138-155.

[2] Biggs, J. and Tang, C. (2011). Teaching for Quality Learning at University.4th ed. Buckingham: Society for Research into Higher Education and Open University Press.

[3] Bradley-Levine, J., Berghoff, B., Seybold, J., Sever,R., Blackwell,S. and Smiley, A.(2010). What Teachers and Administrators "Need to Know" about Project-Based Learning Implementation. In: Annual Meeting of the American Educational Research Association. [online] Denver, CO: pp. 1-26. Available at:

[4] https://www.dr-hatfield.com/science rules/articles/WHAT \%20TEACHERS\%20AND\%20ADMINISTRATORS\%20 NEED\%20TO\%20KNOW\%20ABOUT.pdf [Accessed 19 Mar. 2019]. 
[5] Buddle, C. (2013). Using Mobile Technology to Engage Students in Inquiry-Based Learning. [video film] Available at: https://www.youtube.com/watch?v=xdSpQOVDss4 [Ac cessed 15 Mar. 2019].

[6] Dearnley, C. A., Coates, C., Dransfield, M., Fairhall, J., Haigh, J., Hennessy, S., Parks, M., Riley, K. and J. Taylor. (2009). Using Mobile Technologies for Assessment and Learning in Practice Settings: Outcomes of Five Case Studies. International Journal on E-Learning, 8(2), pp. 193-207.

[7] De Graaff, E. and Kolmos, A. (2007). "History of Problem-Based and Project-Based Learning." In: E. De Graaff and A. Kolmos, eds., Management of Change: Implementation of Problem-Based and Project-Based Learning in Engineering, 1st ed. Rotterdam: Sense, pp. $1-8$.

[8] De Los Ríos, I., Cazorla, A., Díaz-Puente, J. M. and J. L. Yagüe. (2010). Project-Based Learning in Engineering Higher Education: Two Decades of Teaching Competences in Real Environments. Procedia Social and Behavioral Sciences, 2, pp. 1368-1378.

[9] Dewey, J. (1897). My Pedagogic Creed. The School Journal, Vol. LIV, No. 3, pp. 77-80. Available at: http://playpen.meraka.csir.co.za/ acde/education/Dr_Anvi nd Gupa/Learners Library 7 March 2007/Resources/boo ks/readings/17.pdf [Accessed 25 June, 2019].

[10] Donnelly, R. (2005). "Using Technology to Support Project and Problem-Based Learning." In: T. Barrett, I. Mac Labhrainn and H. Fallon, eds., Handbook of Enquiryy and Problem-Based Learning: Irish Case Studies and International Perspectives, 1st ed. Galway, Ireland: Celt, pp. 157-177.

[11] Donnelly, R. and Fitzmaurice, M. (2005). "Collaborative Project-Based Learning and Problem-Based Learning in Higher Education: A Consideration of Tutor and Student Role in Learner-Focused Strategies." In: G. O'Neill, S. Moore and B. McMullin, eds., Emerging Issues in the Practice of University Learning and Teaching, 1st ed. Dublin: AISHE/HEA, pp. 87-98.

[12] Educational Technology and Mobile Learning (2014). 30 of the Best Apps for Project-Based Learning. [online] Available at: http://www.educatorstechnology.com/2014/0 3/march-31-2014-project-based-learning-is.html [Accessed 10 Mar. 2019].

[13] Elgort, I., Smith, G. A. and Toland, J. (2008). Is Wiki an Effective Platform for Group Course work? Australasian Journal of Educational Technology, 24(2), pp. 195-210.

[14] Frank, M. and Barzilai, A. (2004). Designing Course Web Sites for Supporting Lecture-Based Coursed in Higher Education - Some Pedagogical Aspects. [Online] International Journal of Instructional Technology \& Distance Learning, 1(12). Available at: http://www.itdl.org /Journal/Dec_04/article04.htm [Accessed 22 Mar. 2019].

[15] Harmer, N. (2014). Project-Based Learning, Literature Review. [pdf] Plymouth: Plymouth University, pp. 1-34. Available at: https://www.plymouth.ac.uk/uploads/product ion/document/path/2/2733/Literature_review_Project-base d_learning.pdf [Accessed 25 Mar. 2019].

[16] Henri, T. R. (2013). Forming Productive Student Groups
Using a Massively Parallel Brute-Force Algorithm. Lecture Notes in Engineering and Computer Science, 1, pp. 108-112.

[17] Kahn, P. and O'Rourke, K. (2004). Guide to Curriculum Design: Enquiry-Based Learning. York: Higher Education Academy, Imaginative Curriculum Network. Available at: http://www.campus.manchester.ac.uk/ceebl/resources/guid es/kahn_2004.pdf [Accessed 28 Mar. 2019].

[18] Lathika, K. (2016). Student Centred Learning. International Journal of Current Research and Modern Education 1(1), pp. 677-680.

[19] Lee, J. S., Blackwell, S., Drake, J. and Moran, K. A. (2014). Taking a Leap of Faith: Redefining Teaching and Learning in Higher Education through Project-Based Learning. Interdisciplinary Journal of Problem-Based Learning, 8(2), pp. 19-34.

[20] Lehmann, M., Christensen, P, Du, X. and Thrane, M. (2008). Problem-Oriented and Project-Based Learning (POPBL) as an Innovative Learning Strategy for Sustainable Development in Engineering Education. European Journal of Engineering Education, 33(3), pp. 283-295.

[21] Logan, K. and Neumann, T. (2010). Comparison of Blackboard 9.1 and Moodle 2.0. Report Prepared for the Institute of Education, University of London. [online] London: IOE, pp. 1-18. Available at: http://studylib.net/do c/8676165/comparison-of-blackboard-9.1-and-moodle-2.0 [Accessed 17 Mar. 2019].

[22] Markham, T., Larmer, J. and Ravitz, J. (2003). Project Based Learning Handbook: A Guide to Standards-Focused Project Based Learning for Middle and High School Teachers. 2nd ed. Novato, CA: Buck Institute for Education.

[23] Mills, J. E. and Treagust, D. F. (2003). Engineering Education - Is Problem-Based or Project-Based Learning the Answer? Australasian Journal of Engineering Education, 3, pp. 2-16.

[24] Nanney, B. (2004). Student-centered learning. Retrieved from http://ollysofalhaj.ipgkti.edu.my/sumber/resosbestari/ PENDEKATAN/scl/7\%20SCL-Nanney.pdf [Accessed 25 June, 2019].

[25] Page, R. (2008)."Using Wikis to Support Small Group Work." Advance online publication. Available at: http://english.heacademy.ac.uk/2016/01/24/using-wikis-tosupport-small-group-work/ [Accessed 17 Mar. 2019].

[26] Pawson, E., Fournier, E., Haigh, M., Muniz, O., Trafford, J. and Vajoczki, S. (2006). Problem-Based Learning in Geography: Towards a Critical Assessment of its Purposes, Benefits and Risks. Journal of Geography in Higher Education, 30(1), pp. 103-116.

[27] Saukkonen, J. (2014). Effects of Project-Based Learning in Education-Enterprise Collaboration to Learning Experience and Students Engagement. [Online] Finnish Business Review. Available at: http://urn.fi/urn:nbn:fi:jamk -issn-2341-9938-4 [Accessed 28 Mar. 2019].

[28] Saulnier, B.M., Landry, J.P., Longenecker, H.E. and Wagner, T.A. (2008). From Teaching to Learning: Learner-Centered Teaching and Assessment in Information 
Systems Education. Journal of Information Systems Education: 19(2), 169-174.

[29] Srba, J. (2010). An Experiment with Using Google Tools for Project Supervision at Tertiary Education. In:The 11th International Conference on Computer Systems and Technologies and Workshop for $\mathrm{PhD}$ Students in Computing on International Conference on Computer Systems and Technologies.[online] Sofia: CompSysTech, pp. 430-435. Available at: http://people.cs.aau.dk/ srba/fil es/Srba:CompSysTech:10.pdf [Accessed 12 Mar. 2019].

[30] Thomas, J. W. (2000). A Review of Research Project-Based Learning. Report Prepared for The Autodesk Foundation. [online]San Rafael, California: Autodesk Foundation, pp. 1-45. Available at: https://www. asec.purdue.edu/lct/HBCU/documents/AReviewofResearc hofProject-BasedLearning.pdf [Accessed 22 Mar. 2019].

[31] Tolsby, H., Nyvang, T. and Dirckinck-Holmfeld, L. (2002). "A Survey of Technologies Supporting Virtual Project Based Learning." In: S. Banks, ed., The Third International Conference on Networked Learning, 1st ed. Sheffield: University of Sheffield, pp. 572-581.

[32] Utulu, S. C. and Alonge, A. (2012). Use of Mobile Phones for Project Based Learning by Undergraduate Students of Nigerian Private Universities. International Journal of Education and Development using Information and Communication Technology (IJEDICT), 8(1), pp. 4-15.

[33] Vasilienè-Vasiliauskienè, V., Butviliene, J. and Butvilas, T. (2016). Project-Based Learning: The Complexity and Challenges in Higher Education Institutions. Computer Modeling \& New Technologies, 20(2), pp. 7-10.

[34] Vygotsky, L. S. (1978). Mind in society: The development of higher psychological processes. Cambridge, MA: Harvard University Press.

[35] Weenk, W., Govers, E, and Vlas, H. (2004). Training in Project-Based Education: Practice as You Preach. European Journal of Engineering Education, 29(4), pp. 465-475.

[36] Yiping, L. and MacGregor, S. K. (2004). Enhancing Project-Based Learning Through Online Between-Group Collaboration. Educational Research and Evaluation, 10(4-6), pp. 419-440. 